\title{
Promoting Human Rights in the Era of Globalization and Interventions: The Changing Spaces of Struggle
}

\section{MICHELINE ISHAY}

University of Denver

ABSTRACT A new cartography of geopolitical and corporate interests is reshaping the international order after September 11, calling into question the state's ability to secure fundamental rights for its citizens and to preserve participatory democracy. If civil society tends, among human rights activists, to be the preferred venue to articulate human rights concerns against the state and other powerful entities, one may wonder whether civil society has not become an arena dominated by consumerism or the pursuit of security. With the weakening of social forces for human rights in civil society as a buffer between the state and the private realm, how can we protect individuals from deepening incursions by the state and the globalized market in our age of war against terror? This article considers these issues, by placing them in historic context. More specifically, it examines how selected events since the Second World War have transformed the spaces which support and shape campaigns for human rights struggle.

Contemporary discussions over the best agency for the promotion of human rights (e.g., the feminist movement, the ecological movement, NGOs, the UN, the state, etc.) generally disregard how structural and institutional dynamics form a totality, which has historically favored or restricted opportunities to advance human rights. Human rights scholars and activists tend to focus on civil society as the best arena for human rights struggle against the state, overlooking how different state apparatuses mold and shape their power in relationship to civil society (Barber, 1996; Walzer, 1999). ${ }^{1}$ Few have considered how this dynamic may impact on the private realm (e.g., the individual right to privacy, gender relations, child rearing, our capacity for critical thinking, etc.). This article seeks to address these lacunae.

As globalization progresses, the state seems less able to ensure a fair diffusion of information and to secure the social environment necessary for real democratic debate. Forced out of the 
piazza popolare by corporate behemoths, progressives are either calling for the rebirth of local politics and communitarian solidarity, or for global action-both virtual and institutional. Whether progressive activities are now local or global, however, civil society is in danger of being left at the mercy of tycoons. Movements animated by universal human rights principles (or democratic social forces) — as opposed to social forces animated by nationalist and religious fervor or exclusionary agenda-have been weakened as a traditional buffer to state authority. Left increasingly paralyzed by market imperatives and post-September 11 security concerns, human rights activism has been gradually superseded by new authoritarian trends.

Historically, technology, economic development and the state contributed first to the development and only later to the diminishing of social spaces of communication essential to the human rights struggle. The railroad and the industrial revolution, for example, spawned new urban sites of human interaction, creating spaces for new forms of resistance (e.g., trade unions, labor movements, etc.) often directed against the ramifications of these same new economic developments. Today, in the information age, globalization and flexible production have fragmented and diluted the capacity for resistance. Now digitalized and mediatized, the democratic vox populi may be easily subjected to corporate and military interests. At the same time, these global forces may well be carving out new social spaces propitious for the human rights struggle, as digital photography and the Internet combine to place once hidden horrors on instant global display.

To understand the contradictory impacts of globalization on human rights, this article proposes to explore how globalization has shaped the state, civil society (or the public sphere) and the private sphere. Drawing on Antonio Gramsci, the state is referred to here as an organism 'reinforcing the relative power of the bureaucracy (civil and military), of high finance, and generally of all bodies relatively independent of the fluctuation of public opinion proper' (Gramsci, 1980). ${ }^{2}$ With Gramsci, civil society is understood as the realm both of commodity exchange and social relations between dominant and subaltern groups, a social arena molded by the state to fit existing economic structures. Following Jürgen Habermas, the private sphere indicates either the realm of personal or the household, a realm that became a separate entity with the emergence of the bourgeois public sphere (Habermas, 1991).

One may wonder whether traditional channels for promoting human rights (i.e., in the state and various domestic and international associations within civil society) have been adversely impacted by globalization, and whether new human rights strategies must now be devised. As a new cartography of power is reshaping the international order after September 11, one may ask, now more than before, whether the state is still able to ensure fair access to information, and to secure the social environment necessary for authentic democratic debate and the advancement of human rights. Has civil society, both locally and globally, become an arena dominated by either consumerism or security interests? If democratic forces in civil society are weakening as a buffer zone between the state and the private realm, how can we protect private individuals from deepening incursions by the state (its military apparatus) and the market? This article addresses these questions, focusing on the impact of the economy and institutions over changing spaces of human rights struggle as a result of the advance of globalization.

\section{Globalization and the State}

As the world becomes more economically integrated, a new grid of power connecting its disparate parts throughout the world around informational and economic sites, many argue, now rivals the traditional state apparatus, blurring the old binary distinction between North and South, and 
creating a new 'medieval' landscape of power centers (Sassen, 1998; Held et al., 1999). While written from differing ideological perspectives, the post-Cold War academic literature announcing the demise of the state has often questioned the state's ability to curtail market forces and to ensure social benefits and human rights (Ohmae, 1995; Wriston, 1992; Guehenno, 1995, Strange, 1996; Negri and Hardt, 2000). Global economic integration, so goes the argument, is eroding hard won rights - especially workers' rights-in the developed West, while precluding the achievement of those rights in the developing world (Tilly, 1995).

While the state is indeed changing, it is hardly disappearing. Far from it. The progress of neoliberal economic globalization requires a strong state to guarantee sufficient education and living standards to enable citizens to maintain purchasing power (Panitch, 1994), or to maintain authoritarian governmental structures that ensure property rights and cheap labor and suppress opposition. To be more precise, it is not the state that is weakened, despite widespread belief to the contrary, but rather its capacity to sustain the redistributive policies associated with the welfare state. More than that, if the old imperialist divide between Southern and Northern states has been challenged by the emergence of industrialized East Asian states and other new economic loci of economic power on the international scene, 'Northern' or 'Western' states still remain far more influential. It is Western authority that prevails in international organizations (the UN, the WTO, the IMF, etc.), and in its ability to dispatch military forces to retaliate against challengers, or to secure its interest in the new global order.

No sooner had the Cold War ended than that the new global order was tested by the Iraqi invasion of Kuwait. Whatever the virtues of the US-led coalition's proclaimed commitment to defending the sovereignty of threatened states, the propelling force behind the Desert Storm campaign was surely the aim to ensure Western access to the region's oil (Robinson, 1996). Yet such blatant economically and geopolitically driven interventions cannot command the world respect needed to sustain American (or Western) hegemony. That instrumental goal was better served by the 1999 Kosovo intervention, which helped secure regional stability for Europe's troubled backyard, as even critics of NATO's bombardment conceded (Chomsky, 1999). Moreover, the bombing arguably prevented far worse massacres and human rights abuses, as evidenced by the record of Slobodan Milosovic's (1941-) Serbian forces when left free to conduct a war in Bosnia.

If hegemony, as Gramsci understood it, requires a moral justification of power, the Western powers have met that standard only intermittently, notably failing to intervene even in cases of genocide. It is certainly true that the British intervention in Sierra Leone in 1999 put a halt to massive bloodshed, just as an Australian-led force halted the slaughter in East Timor that same year. Yet, no one, despite faint gestures of interest, had intervened to interrupt the 1994 genocide in Rwanda, in which hundreds of thousands of women, children and men met a terrible death (Power, 2002; Falk, 2000). For too many years, the West had remained motionless in the face of monstrous oppression, particularly against women, under the Taliban regime, until the appalling wakeup call of September 11 2001. And now, as a new campaign of genocide unfolds in Sudan, the wealthy nations are still unforgivably quibbling over whether to stop the tragedy. Morality and interest need to be recurrently wed to ensure the perpetuation of hegemonic dominance. If some response toward a regime as repressive as the Taliban was long overdue, it surely would not have occurred had not the security of the world's most powerful state been put directly in jeopardy.

This and other military actions, years after the end of the Cold War, remind us that the state is not about to fade away, and that it might even promote humanitarian causes within the framework of new just war theories. If anything, effective use of force ultimately strengthens the 
juridical and moral apparatus of a globalized world in the service of its most privileged custodians, who without hesitation warn belligerent defiers of core centers of globalization of the terrible price of rebellion and disruption. In this sense, globalization appears 'in the form of a very high tech machine: it is virtual, built to control the marginal event, and organized to dominate and when necessary intervene, in the event of the breakdown of the system' (Negri and Hardt, 2000, p. 39).

Thus, in the fight against terrorism, the world is enjoined to fearfully coalesce against 'evildoers', behind the power of 'civilization', which, however, in a not too distant past, was (and remains in certain regions) guilty of the greatest indifference to human suffering. Nonetheless, skepticism toward the current deployment of idealistic rationales (e.g., women's rights, democracy, development) for the war on terror should not suggest that patterns of past wrongdoing should not be redressed or that interventions-diplomatic, economic or military-should not be considered to halt genocide or stop severe human rights violations.

Yet defenders of humanitarian interventions (who understand that human rights rhetoric may mask instrumental interests) should remain cautious in defending the use of all possible means in the pursuit of human rights ends. Thus, human rights advocates had good cause for concern that military intervention aimed at toppling the Iraqi dictator Saddam Hussein (1937-), who had undertaken a genocidal assault on his own Kurdish population in 1988, might ignite a broader conflict in the Middle East, engulfing the Arab world and Israel, an outcome that would mock the goal of peace and human rights. In some cases the costs are obviously prohibitive, making rescue of the oppressed unimaginable. Could anyone seriously envision a Western- or UN-sanctioned military intervention to 'liberate' the Chechnyans from abusive Russians or the Tibetans from suppression by China?

While global economic integration ostensibly weakens the state, the primary economic beneficiaries of globalization need a strong state in part to crush popular or ethnic challenges. Yet, the fact that the state is porous to global market pressures should not imply that human rights activists should abandon in toto the state's legislative and enforcement capacity to promote democracy and human rights. To do so would be accept a reshaping of state power in which the strengthening of the coercive machinery to crush domestic or foreign opponents proceeds in tandem with a weakening of welfare, workers' rights, and democratic governance-a world designed to offer 'carte blanche' to corporate and geopolitical interests.

\section{Globalization and Civil Society}

If global economic integration and post-Fordist production have weakened the welfare capacity of the state, they have also restructured civil society worldwide by strengthening corporate interests and adjusting the role of the state to conform to new economic rules. One can hope, drawing from the lessons of the nineteenth century, that the weakening of the state will be conducive to the expansion of a vibrant civil society. As new forms of production and global economic integration have undermined the state's propensity to enforce workers' rights and social justice, is civil society (understood both locally and internationally) emerging as a better forum for the advancement of human rights? Two trends can be identified with respect to human rights in civil society: a negative trajectory, if we consider, in the domestic realm, the ascension of nationalist and extremist religious forces and the weakening of democratic social movements, particularly after September 11, and a positive path, should we consider, in the international realm of civil society, the proliferation of international human rights institutions and the growth of the 'anti-globalization' movement. 
In the West, the decline of organized labor, whose unified agenda has been supplanted by the diverging interests of groups promoting feminist, environmental, racial, ethnic, gay and other issues, reflects such a negative trend. Given their inability to achieve a meaningful allianceessential for channeling demands and collective bargaining-the influence of progressive forces has been substantially curtailed since the 1970s. In parallel with the United States, trade unions have also been severely weakened in Europe, as evidenced by the 1991 Maastricht agreement.

The frustration of nationally based labor unions in the West has been echoed by the embattled efforts to develop peasant solidarity in developing areas such as India, Bangladesh and Sri Lanka, coupled to a failure thus far to broaden what remain disconnected local struggles, from Beijing to Chiappas, Jakarta, Seoul and elsewhere. 'The paradox is that in our age of communicability, these struggles have become all but incommunicable, and the very notion of international struggle based on the communication of common desires seem to have vanished.' (Negri and Hardt, 2002, p. 39). In the cracks of this fractured social terrain, the seeds of nationalism have sprouted and sunk new roots.

Despite pockets of resistance driven by a human rights agenda, whether in the form of Western social movement activism or in other forms of local contestation, nationalist movements from Le Pen's party in France to the Hamas movement in the West Bank have been the prominent forms of resistance against the permeation of globalized capital and Western cultural influence. Nevertheless, if nationalists despise globalization in principle, they have not hesitated to utilize the technologies unleashed by globalization to acquire weapons and to disseminate their message. Indeed, as in the Iranian revolution, groups as disparate as the Hutus and Serbs, among others nationalists, have relied heavily on the mass media to fuel nationalist, religious or ethnic fervor. In the United States, fundamentalist Christian groups and neo-Nazis have utilized sophisticated websites and internet campaigns to recruit new members, coordinate activities and disseminate their agenda (Berlet, 1998).

Ironically, groups from the extreme right to the radical left-among them nationalists, religious fundamentalists, communitarians and peasant movements worldwide-share a common spatial and communal orientation in their reaction against the acceleration of time and the obtrusion of globalized capital upon every localized identity. Rejecting a civil society shaped by the rule of homo economicus, many have sought to invest their strength in local politics. In the post-communist world and in the developing countries as well, abhorrence of the state and a focus on civil society have been the prevailing impulses for many dissenters and activists. Yet what was not anticipated by grassroot activists in these societies was the ability of stronger corporate forces to take substantial control over civil society, and to trample resistanceespecially progressive resistance-without any fear of corrective state regulation.

In the Western world, a similar trend has been noticeable. From the religious right, typified by American evangelists like Jerry Falwell and Pat Robertson, which emphasizes communal love around the institution of the church, to Canadian and American liberals like Charles Taylor and Alvin Toffler, who ask for non-interference in community or local politics centered around civic organizations or 'virtual' communities, to ecologists celebrating local as well as global militancy, the state and the global economy are similarly regarded as unwelcome intrusions into civil society (Taylor, 1994; Toffler, 1981). Yet it is doubtful that such personal or local politics within civil society will be any more impermeable than the state to the market-driven forces of the information age (Barber, 1995). If anything, local spaces of contestation, whatever their ideological origins, can be easily commodified, co-opted, and when necessary, violently neutralized by globalizing forces. 
The game is not entirely one sided, however. One can witness, indeed, a more positive trend for human rights opportunities on the international front of civil society. In 1956, for instance, there were 973 transnational non-governmental organizations (NGOs), whereas in 1996 there were over 5,000 (Friedman, 1999). Of these 5,000, one may now count over 200 US NGOs associated with human rights issues in the United States, a comparable number in the UK and the spread of similar organizations in the developing world (Held et al., 1999). Lester Salmon, director of Johns Hopkins Institute for Policy Studies, notes the general difficulty in compiling systematic data, given the 'varying terminology and widely divergent functions' of the non-profit civil sector (Salamon, 1994). Nevertheless, the rapid global expansion of the organized human rights movement since the 1970s is beyond dispute, and one should consider how the emergence of such global issues as development and the environment are associated with the rapid proliferation of supranational organizations aspiring to fulfill functions traditionally assumed by the welfare state.

Paralleling this expansion, one can also observe the proliferation of human rights legal documents, ratified by growing intergovernmental organizations (IGOs). With only 37 IGOs in 1909, at present one can count nearly 241 IGOs, and 2,072 multilateral treaties and intergovernmental agreements, and a significant increase in the level of diplomatic interaction (Union of International Associations, 2000). Along with increasing trade, foreign investment, cultural exchanges and tourism, there has been an unprecedented spread of global human rights mechanisms-e.g., the European Commission of Human Rights, the InterAmerican Committee on Human Rights, among many other human rights IGOs-a trend propitious for the passage of international human rights legislation and for the development of what some have called a human rights regime (Held et al., 1995; Donnelly, 1994; Crawford, 1994).

More specifically, there have been indications of strengthened international law pertaining to perpetrators of war crimes and crimes against humanity, exemplified by the indictment and extradition of the former Chilean ruler Alfonso Pinochet and the former Serbian president Slobodan Milosovic. Also noteworthy has been the development, in South Africa, of an alternative to such prosecutions, as the Truth and Reconciliation Commission offered freedom to those guilty of murderous abuses during Apartheid, in exchange for a full confession of their crimes. That innovation has proven a creative approach that publicly documents human rights violations, airs the grievances of survivors, and engenders a healing process that exchanges vengeance for reconciliation and the promise of a better future. While power politics continues to prevail, as illustrated by the United States' unwillingness to recognize the International Criminal Court, the near unanimous rejection of the US view by the international community reflects apparent progress in the construction of a global human rights regime.

These and other human rights initiatives have benefited from growing visibility, as information technology has enhanced the expansion, influence and networking capacity of human rights-oriented NGOs and IGOS. From the growing prominence of groups like Amnesty International, Human Rights Watch, and Médecins sans Frontières, to the post-Cold War appeal of arguments for humanitarian intervention, human rights discourse is now playing an important role in world politics. Human rights websites have become a major tool for the dissemination of information about human rights violations, for rallying popular outrage and for pressuring governments to redress human rights transgressions. Repressive states can no longer easily insulate their populations from the diffusion of information, as radio broadcasts of unauthorized views (such as by the Voice of America and BBC World service) have been supplemented by the interactive capabilities represented by websites and e-mail. For more open societies, the 
triumph of technology over efforts to hide abuses was dramatically evidenced by the worldwide graphic display of the abuse of Iraqi prisoners by their US captors.

Proposals to counter encroachments on human rights by the market and the state, either by strengthening global democratic institutions, or by developing a global virtual space of human rights action, have become a subject of great academic interest. Robert Keohane, Joseph Nye and John Ruggie, among others, have identified the importance of new regimes as ways to sanction abusive governments (Nye, 1996; Keohane, 1984; Ruggie, 1998). Robert Johansen and David Held have proposed ways to restructure international institutions, such as the UN and its Security Council, to make them more democratically representative (Johansen, 1994; Held, 1995). Others, like Jessica Matthew Tuchman (1997), Iain McLean (1989), and Margaret E. Keck and Katheryn Sikkink (1998) have shown the importance of NGOS and the use of information technology to pressure repressive governments to adopt human rights measures-citing the Chiappas rebellion and other cases where challenges to ruling elites tempt repressive governmental responses.

Without questioning the important contributions of transnational institutionalism or the diffusion of information, it still remains unclear, however, why in a non-regulated global environment, corporate interests would not once again be better equipped (given their enormous financial resources) to influence global institutions such as the IMF, World Bank and IGOs and NGOs, as well as the virtual civil society (through ownership of the telecommunications industry, advertisements, control over World Wide Web portals, etc.), while simultaneously seeking legitimacy by maintaining a largely cosmetic universalist rhetoric of human rights. As Habermas reminds us, 'the most fortunate nations had [already] learned in the eighteenth century how sheer power can domesticate legitimate law' (Habermas, 2001).

Is the human rights regime, after all, mere window dressing, serving mainly to conceal the interests and clout of the powerful? Positive international human rights laws, while important, are far from sufficient: there is a need to offer new channels for repressed inhabitants of countries with weak or non-existent liberal institutions to express their demands for democratic accountability. Already, there are signs - if only tentative and intermittent-that the mass global protests against meetings of the IMF and G8, and the convening of various Social Forums throughout the world, are having an impact. The policy of imposing 'austerity measures' on debtor nations is yielding to greater recognition of the need to address the problems of the world's poor. Yet while shifting our focus toward popular democratic and collective action is critical, one should not forget that local and transnational human rights efforts remain fragmented.

Globalization has undergone substantial changes since the beginning of the Cold War, changes that had different impacts on labor, environmental, immigration and cultural rights, groups, cultures, classes and regions of the world. Even as globalization has propelled a new wave of human rights activism, debate over its relationship to economic inequity has deepened tensions within human rights NGOs and the grassroots community, thereby fragmenting and bankrupting the social capital of these and other activists. The war against terror has accentuated that division within global civil society. In the absence of consistent legal criteria and in the face of wavering UN policy regarding human rights, activists have oscillated between two opposite poles. Critical of the unchallenged economic and military hegemony of the United States and at the same time revolted by the inaction of other states in particular instances of gross human rights violations, the human rights community has been struggling to develop a more coherent position. In their simultaneous fight against the United States (or NATO) as self-proclaimed enforcer of human rights and against human rights violators, many welcomed (at least tacitly) the humanitarian interventions in Somalia and Haiti, deplored the indifference of the world, and particularly the 
paralysis of the United States, during the massacres in Bosnia and the genocide in Rwanda, and criticized military interventions in Kosovo, Afghanistan and Iraq-despite the fact that targets of intervention were among the world's worst abusers of human rights.

The ambivalence within the human rights community over alleged humanitarian interventions, just as over the effects of globalization, has created fertile soil for the appropriation of universal human rights principles by influential political and economic actors. Theoretically, while the 'anti-globalization' movement provides new hopes and opportunities for the development of a more vibrant global civil society and integrated human rights dialogue, it still lacks a common progressive political, economic and social agenda: an important denominator needed to unite more effectively a variety of human rights interests. Strategically, and particularly in light of September 11, a more comprehensive universalist agenda should engage the reality of the new security order and seize opportunities wherever they present themselves. Steps toward a common agenda would in turn enable human rights activists to explore more systematically ways to coordinate local and global human action, thereby avoiding needless duplication and redirecting resources where most needed.

In short, a human rights agenda built on greater political, social and economic cohesiveness and deployed to coordinate local and global human rights action might advance the ongoing struggle to strengthen the capacity of the state to resist corporate demands for deregulatory policies and self-serving geopolitical interest. Whether human rights efforts are invested locally or transnationally, they are often conducted outside and against the state; a forum which remains, despite many skeptics of the legitimacy of the Westphalian system, a critical vehicle for the promotion of human rights. In the absence of a buffer zone able to maintain and regulate the state and the global economy, the private realm (including the family as well as the realm of privacy) faces greater challenges.

\section{Globalization and the Private Realm}

Since the Second World War, the realm of the family has been substantially transformed in relationship to the economy and the state. Shortly after the Second World War, France, Yugoslavia and China were added to the group of nations, (already including the United States and Great Britain), that had granted voting rights to women. In the Western world, the 1960s and 1970s saw the flourishing of women's movements which, along with the development of the counter-culture, the New Left, the new social movements and gay organizations, joined the struggle against individualism, conservative family values and the war in Vietnam. The feminist movement in particular changed the social landscape. With the development of affirmative action, abortion rights and other forms of legal protection, women have grown more disposed to assert their independence, to divorce when they wished, and to join in growing numbers a predominantly male public space.

As inflation and recession in the 1970s made it hard to support even intact families on a single income, a great number of women, including those with young children, entered the workforce. The market, unsurprisingly, did not reject this influx of a new surplus labor pool willing to work for lower wages - especially given the resultant downward pressure on men's salaries. As the number of divorces started rivaling the number of marriages, and a harsher competition between men and women in the workplace triggered a new 'battle of the sexes', affirmative action was challenged in a process that Susan Falludi has aptly described as the 'backlash' against feminism (Faludi, 1991). The attack on welfare during the Thatcher and Reagan era ultimately undercut women's living conditions, particularly those of single mothers, increasing numbers of whom fell below the poverty line (Mink, 1998; Garfinkel and McLanahan, 1986; 
Seavey, 1996). Not only did the disintegration of the family parallel the fragmentation of social and democratic forces in civil society, it also destroyed the equilibrium between a patriarchal civil society and a feminine domestic household. With the gradual disappearance of a rigid gender division of labor, and without the sanctuary of a secure private household under the care of women, the struggle for survival in the public sphere became harsher.

It is in this context that one can explain the success of politicians in their crusade for anachronistic notions of 'family values', the attack on affirmative action (which in the United States has primarily affected the black population) as well as on women's reproductive freedom, and the widespread disdain for feminism at every level of society. From the bombing of abortion clinics, to the Southern Baptist Church's insistence on a wife's subordination to her husband, the backlash against American feminism is in full swing. In less stable and more violence-prone regions of the world, women were prone to losing even minimal protections - as witnessed by the abolition of women's education by the Taliban in Afghanistan, the killing of secular women by Islamist insurgents in Algeria, the 'rape camps', run by the Serbian government of the former Yugoslavia, and the spread of Islamic 'laws' (from Saudi Arabia to Iran to Nigeria) in which women convicted of adultery in all-male courts may be stoned to death.

Social stability is challenged when both the family and civil society are in disarray. In the absence of democratic forces in the public space, should we be surprised that patriarchal control over women in Middle Eastern societies, a replica of authoritarian power on the domestic level, appeases and empowers Muslim men while diverting them from unleashing their frustration against the repressive state? Should we be surprised that in the absence of a vibrant civil society in the West, political interest, as in the United States, often takes the form of a fascination with sexual politics, as illustrated by the preoccupation with President Clinton's liaisons with Jennifer Flowers, Monica Lewinski and allegedly others, with Princess Diana's romantic life, with O.J. Simpson's battered and murdered wife, or with Congressman Gary Condit's murdered mistress Sandra Levy. Should we be surprised when the media mirror household concerns in the political realm, or when the affairs of the state are reduced to the politics of domesticity?

Did we too hastily desert the public space for the magical realism of tabloid politics? The vanishing of a physical democratic public space at the local level is already well advanced once public discourse has been supplanted by media talking heads, when participatory democracy has been superseded by opinion polls, when teenagers meet in the malls but are rarely seen at political rallies or as volunteers for political organizations, and when Scott Peterson's trial becomes more politically important than the plight of Afghan, Nigerian, Saudi or Sudanese women.

While connecting us faster, information technology is now more than ever invading our realm of privacy, whether one is a celebrity or an ordinary citizen. Concerns over the protection of private information, fears of outsiders' reading of e-mail, employees' identification of prospective employees' choices of websites, and issues of intellectual property on the web: all underline the fragility of individual rights (Doheny-Farnia, 1996; Gurak, 1997). In the wake of terrorist attacks, we recognize that we have become even more vulnerable as we become more globally linked. Border and airport controls have been tightened, measures protecting privacy have been removed, identification requirements and background checks proliferate, paving the way to an ever more pervasive surveillance society.

If greater state control provides more security, it ultimately undermines civil liberties and the fundamental right to privacy. Sophisticated face recognition technology and cameras deployed throughout England as part of a broad national surveillance plan provide a glimpse into what may be in store for America. If designed initially to combat terrorism, British video surveillance is now mainly used to follow car thieves and traffic offenders, confess officials at the monitoring 
room for the City of London. It is also used to keep punks out of shopping malls, and 'rather than thwarting serious crime, the [dummy as well as real] cameras are being used to enforce social conformity' (Rosen, 2003).

The British utilitarian philosopher Jeremy Bentham (1748-1832) already understood the appeal of constant surveillance more than two centuries ago, when he described the social benefits of building a guard tower that gazes over the inner walls of a prison, whose inmates must henceforth live in constant fear of being watched. That uncertainty, he believed, would deter inhabitants of this 'model' prison, which he called the Panopticon (Greek for 'all seeing place'), from engaging in anti-social behavior:

The more constantly the persons to be inspected are under the eyes of the persons who should be inspecting, the more perfectly will the purpose of the establishment have been attained. Ideal perfection, if that were the object, would require each person should actually be in that predicament, during every instant of time. This being impossible the next thing to be wished for is, that, at every instant, seeing reason to believe as much, not being able to satisfy himself to the contrary, he should conceive himself to be so. (Bentham, 1995)

Technology, as Michel Foucault observed, has finally approached the realization of Bentham's vision of modern surveillance, facilitating, as each individual internalizes the sense that all behavior is being monitored, the implementation of ever more efficient and less visible forms of state control (Foucault, 1995). In contrast to the often brutal and public forms of punishment of the past, modernity and globalization, claimed Foucault, have introduced cleaner and more rational forms of social control and punishment.

The expansion of counter-terrorist activities, then, did not instigate but rather accelerated the rise of a more bureaucratized cyber-controlled society (Lyons, 1994, ch. 2). Max Weber predicted this trend almost a century ago, observing the depersonalization of civil society at a far earlier stage of bureaucratization. More recently, L. Ron Hubbard, the founder of Scientology, tapped that source of individual anxiety in the West when he proposed elevating science to a religious faith, while in some less developed regions of the world, Mullahs find new responsiveness to a more traditional vehicle for depersonalization. One can argue that we have moved back toward a new form of medieval and religious social landscape, in which the focus on the local and the fragility of the private realm underlines the absence of sufficient democratic participation in civil society against the state, as a necessary mechanisms for checks and balance.

Protecting the space for critical thinking and privacy, as well as reallocating individual roles within the family in the direction of greater fairness, are important preconditions for revitalizing democratic participation in an increasingly consumer-oriented society. In general, new participatory arenas must be sought to enable citizens to resist the increasingly unregulated intrusion of the state and commercial interests into various arenas of social and personal activities. In turn, a stronger domestic and international participatory civil society can also provide the state with the legitimacy to resist such intrusions by self-interested economic forces, and to act as a more impartial arbitrator between powerful entities and ordinary citizens.

\section{Conclusion}

Post-Fordism after the Second World War has both created new informational sites of economic activity and at the same time decentralized the arenas of social and economic interactions. Yet, global deregulatory economic policies, hastened by the economic crisis of the 1970s, 
have drastically weakened the state's capacity to mediate between capital, on the one hand, and workers and the poor, on the other hand. These changes have allowed the global economy to penetrate more deeply into civil society and the private realm; a trend made manifest by Western politicians' preoccupation with 'smaller' government and private morality.

Disenchanted with the impersonal greed and cynicism of civil society and the crisis of the nuclear family, many individuals are searching for subterfuges in decentralized global villages or under the auspices of churches, mosques and temples. Despite important efforts to advance global communication, particularist, nationalist and fundamentalist forces are on the rise everywhere-in both virtual and non-virtual spaces. In the absence of physical spaces for participatory democracy, and of discourse premised on the promotion of social and economic fairness, the state and the market are already enabled to extend their control over the private realm, well beyond computer and television screens, and well beyond the consciousness of the citizen-spectator of the new Orwellian world, shaping citizens to inhabit passively a one-dimensional world of consumerism, reducing them wherever they live to conformism and uncritical thinking. During the 1960s Herbert Marcuse, later echoed by Vaclav Havel, Benjamin Barber and others, had already identified this trend in modern society.

How can we counter such a return to medieval levels of authoritarian intrusiveness in the private sphere, while reviving the internationalist human rights drive of eighteenth- and nineteenth-century civil society? What venues of human rights hold promise, given shrinking social spaces, that can gather individuals in one setting in a way that enables them to recognize and pursue their collective concerns? The struggles for spatial interaction in the face of an atomized or repressed civil society have never been more important. Though communitarians and nationalists are showing us one path, their narrow spatial and anti-economic foci feed the interests of a dominant economic elite, whose stability and control depend upon the structural separation of diverse social spaces.

If, by contrast, the increase of human rights activism and the subsequent adoption of hundreds of human right treaties offer new hope, enduring change will require the coordination of human rights campaigns with democratic agencies at the level of national and local governance. The struggle for human rights needs to continue both within and beyond the legal debates and the corridors of international organizations. It needs to counter the bureaucratization of the institutionalized human rights regime with mobilization efforts in the streets of locales from Gaza to Guatemala, from Baghdad to Kabul. Developing solidarity between different social agencies of change in the local and global aspects of civil society in turn requires greater efforts to develop an economic and social agenda that unites different human rights efforts.

While a more vibrant civil society could thwart undemocratic policies associated with the unfettered march of neoliberal globalization, protect the realm of privacy against unwelcome state intrusion, and stimulate critical thinking, one should not forget that the popular forces galvanized in 1789 and 1848 benefited from the creation of a nurturing and unremunerated private realm. The feminist movement since the 1970s in the West, however, has more critically challenged that bastion of female subjugation, offering a destabilizing alternative to authoritarian and predominantly patriarchal societies. Ironically, empowering women in the world poorest and more repressive states could well unleash and galvanize democratic forces against repressive states, just as such efforts had stimulated democratic impulses in Western civil societies. It may seem ironic that precisely when problems have become global in scope, we should look to the narrowest space, that of the private realm. Yet it is within that beleaguered temple that we may well find the flame that reignites the Maccabbean human rights rebellions of the new century. 


\section{Notes}

1 There are of course exceptions: John Ehrenberg (1998, pp. 15-18), Jean Cohen and Andrew Arato (1984), Robert Cox (1999) and others.

2 The reader should bear in mind that the relationship I depict between the economy and human rights should be understood not as one of cause and effect, but dialectically, for human rights activities have also helped shaped social and economic activities of each of the aforementioned periods.

\section{References}

Barber, B. (1995) Jihad versus McWorld (New York: Random House).

Barber, B. (1996) An American civic forum: civil society between market individuals and the political community, Social Philosophy and Policy Foundation, 13, pp. 269-83.

Bentham, J. (1995) The Panopticon Writings, ed. Miran Bozovic (London: Verso).

Berlet, C. (1998) Who is mediating the storm? Right wing alternative information network, in Kuntz, Linda \& Lesage, Julia, (eds), Media, Culture and Religious Right (Minneapolis, MN and London: University of Minnesota Press), pp. 249-74.

Chomsky, N. (1999) The New Militarism, Lessons From Kosovo (Monroe, ME: Common Courage Press).

Cohen, J. \& Arato, A. (1984) Social movements, civil society and the problem of sovereignty, Praxis International, 4(3), pp. $266-83$.

Cox, R. (1999) Civil society at the turn of the millennium: prospects for an alternative world order, Review of International Studies, 25, pp. 3-28.

Crawford, J. (1994) Democracy in International Law (Cambridge: Cambridge University Press).

Doheny-Farnia, S. (1996) The Wired Neighborhood (New Haven, CT: Yale University Press).

Donnelly, J. (1999) The social construction of international human rights, in Dunn, T. \&. Wheeler, N.J. (eds) Human Rights in Global Politics (Cambridge: Cambridge University Press), pp. 71-102.

Ehrenberg, J. (1998) Civil Society: The Critical History of an Idea (New York: New York University Press).

Falk, R. (2000) Human Rights Horizons, The Pursuit of Justice in a Globalizing World (London and NY: Routledge).

Faludi, S. (1991) The Backlash: The Undeclared War Against Feminism (New York: Crown).

Foucault, M. (1995) Discipline and Punish, The Birth of the Prison (New York: Vintage Books).

Friedman, T. (1999) The Lexus and the Olive Tree (New York: Farrar, Strauss and Giroux).

Garfinkel, I. \& McLanahan, S.S. (1986) Single Mothers and their Children (Washington, DC: The Urban Institute Press).

Gramsci, A. (1980) Selections from the Prison Notebooks, ed. \& trans. Q. Hoare \& G. Nowell Smith (New York: International Publishers).

Guehenno, J.M. (1995) The End of the Nation-State (Minneapolis, MN: University of Minnesota Press).

Gurak, L. (1997) Persuasion and Privacy in Cyberspace (New Haven, CT: Yale University Press).

Habermas, J. (1991) The Structural Transformation of the Public Sphere (Cambridge, MA: The MIT Press).

Habermas, J. (2001) The Postnational Constellation, Political Essays, ed. \& trans. M.x Pensky (Cambridge, MA: The MIT Press).

Held, D. (1995) Cosmopolitan Democracy: An Agenda for Building a New World Order (Cambridge, MA: Polity Press).

Held, D, Mc Grew, A., Goldblatt, D. \& Perraton, J. (1999) Global Transformations (Stanford, CA: Stanford University Press).

Johansen, R. (1994) Building world security, in Klare, M.T. \& Thomas, D.C. (eds), World Security Challenges for a New Century (New York: St Martin Press), pp. 394-5.

Keane, J. (1998) Civil Society, Old Images, New Visions (Stanford, CA: Stanford University Press).

Keck, M.E. \& Sikkink, K. (1998) Activists Beyond Borders (Ithaca, NY and London: Cornell University Press).

Keohane, R. (1984) After Hegemony: Cooperation and Discord in the World Political Economy (Princeton, NJ: Princeton University Press).

Lyons, D. (1994) The Electronic Eye, The Rise of Surveillance Society (Minneapolis, MN: University of Minnesota Press).

McLean, I. (1989) Democracy and New Technology (London: Polity Press).

Mink, G. (1998) Welfare's End (Ithaca, NY: Cornell University Press).

Negri, A. \& Hardt, M. (2000) Empire (Cambridge, MA: Harvard University Press).

Nye, J. (1996) America's information edge, Foreign Affairs, 75(2), pp. 20-36

Ohmae, K. (1995) The End of the Nation-State (New York: New York University Press).

Panitch, L. (1994) Globalization and the state, Socialist Registrar, pp. 60-93. 
Power, S. (2002) 'A Problem from Hell', America and the Age of Genocide (New York: Basic Books).

Robinson, W.I. (1996) Promoting Polyarchy, Globalization, US Intervention and Hegemony (Cambridge: Cambridge University Press).

Rosen, J. (2001) A watchful state, The New York Times Magazine, 7 October, p. 42.

Ruggie, J.G. (1998) What makes the world hang together? neo-utilitarianism and the social constructivist challenge, International Organization, 52(4), pp. 855-85.

Salamon, L. (1994) The rise of the non profit sector, Foreign Affairs, 73(4).

Sassen, S. (1998) Globalization and Its Discontents (New York: New Press).

Seavey, D.K. (1996) Back to Basics: Women's Poverty and Welfare Reform (Wesley, MA: Center for Research on Women).

Strange, S. (1996) The Retreat of the State: The Diffusion of Power in the World Economy (Cambridge: Cambridge University Press).

Taylor, C. (1994) Multiculturalism, ed. Amy Gutman (Princeton, NJ: Princeton University Press).

Tilly, C. (1995) Globalization threatens labor's rights, International Labor and Working Class History, 47.

Toffler, A. (1981) The Third Wave (London and New York: Bantam Books).

Tuchman, J.M. (1997) Power shift, Foreign Affairs, 76(1), pp. 50-66.

Union of International Associations (2000) Yearbook of International Organizations (Munich: K.G. Saur Verlag).

Walzer, M. (1999) Rescuing civil society, Dissent, 46(1), pp. 62-7.

Wriston, W. (1992) The Twilight of Sovereignty (New York: Charles Scribners Sons).

Micheline Ishay is professor and the director of the Human Rights Program at the Graduate School of International Studies, University of Denver, Colorado. She has written and edited Internationalism and Its Betrayal (University of Minnesota Press), The Nationalism Reader (Humanities and Prometheus Press), The Human Rights Reader (Routledge) and The History of Human Rights, from Ancient Times to the Era of Globalization (University of California Press, 2004). She has also written numerous articles in various human rights and international studies journals. 